Fetal Diagn Ther 1990;5:I-IV

\title{
Contents, Vol. 5, 1990
}

No. 1 Editorial 1

Fetal Tissue Transplantation Research In Support of the Moratorium

Mason, J.0 2

Against the Moratorium

Ryan, K.J 3

Fetal Lateral Cerebral Ventriculomegaly: Associated Malformations and Chromosomal

Defects

Nicolaides, K.H.; Berry, S.; Snijders, R.J.M.; Thorpe-Beeston, J.G.; Gosden, C. . . 5

Development of Human Fetal Behavior: A Review

Pillai, M.; James, D 15

Antenatal Diagnosis and Treatment of Fetal Bronchopulmonary Sequestration

Slotnick, R.N.; McGahan, J.; Milio, L.; Schwartz, M.; Ablin, D 33

New Approaches in Bone Marrow Transplantation: The Utilization of Hematopoietic Stem Cells

Michejda, M.; Peters, S.; De Vleeschouwer, M.H.M.; Bellanti, J.A 40

No. 2 Fetal Urine Production in Normal Twins and in Twins with Acute Polyhydramnios

Rosen, D.J.D.; Rabinowitz, R.; Beyth, Y.; Fejgin, M.D.; Nicolaides, K.H 57

Monozygotic Twinning as a Congenital Defect and Congenital Defects in Monozygotic

Twins

Luke, B.; Keith, L.G 61

Combined Intravascular-Intraperitoneal Transfusions in Hydropic Twins due to Rh (D)

Alloimmunization

Santolaya, J.; Warsof, S.L 70

Increased Severity of Fetal Hemolytic Disease with Known Rhesus Alloimmunization after First-Trimester Transcervical Chorionic Villus Biopsy

Moise, K.J., Jr.; Carpenter, R.J., Jr 76

67Contents

Computer-Assisted Analysis of Fetal Heart Rate Patterns at 20-41 Weeks' Gestation

Snijders, R.J.M.; McLaren, R.; Nicolaides, K.H 79

Ventriculoamniotic Shunt for Treatment of Hydrocephalus in One of Twins: Medical,

Ethical and Legal Considerations

Goldstein, P.; Taylor, W.S.; Zisow, D.; Carson, B.; Shuster, E.; Brodner, R

Fetal Holoprosencephaly: Associated Malformations and Chromosomal Defects

Berry, S.M.; Gosden, C; Snijders, R.J.M.; Nicolaides, K.H 92

Fetal Gastroschisis Complicated by Bowel Dilation: An Indication for Imminent Delivery?

Sipes, S.L.; Weiner, C.P.; Williamson, R.A.; Pringle, K.C.; Kimura, K 100

Amniotic Fluid Pressure during Pregnancy

Sideris, I.G.; Nicolaides, K.H 104

Thyroid Function in Anemic Fetuses 
Thorpe-Beeston, J.G.; Nicolaides, K.H.; Snijders, R.J.M.; Felton, C.V 109

Effect of Maternal and Fetal Characteristics on Diagnosis of Intrauterine Growth Retardation Carrat, F.; Ringa, V.; Blondel, B.; Bréart, G 114

Analysis of Major Histocompatibility Complex Gene Products in Tissues Isolated from the

Developing Human Nervous System

Boyer Kollas, B.; Hartle, H.T.; Wigdahl, B 124

Fetoplacental Blood Volume Estimation in Pregnancies with Rh Alloimmunization

Leduc, L.; Moise, K.J., Jr.; Carpenter, R.J., Jr.; Cano, L.E 138

Catecholamine Levels and Their Correlation to Blood Gases in Umbilical Venous Blood

Obtained by Cordocentesis

Okamura, K; Watanabe, T.; Tanigawara, S.; Endo, H.; Iwamoto, M.; Murotsuki, J.;

Yajima, A 147

Thoraco-Amniotic Shunting

Nicolaides, K.H.; Azar, G.B 153

Does the Color of Amniotic Fluid Still Matter?

Isada, N.B.; Koppitch, F.C., III; Johnson, M.P.; Evans, M.I 165

Evaluation of the Preload Condition of the Fetus by Inferior Vena Caval Blood Flow Pattern

Kanzaki, T.; Chiba, Y 168

Quantitative Analysis of Cardiac Function in Non-Immunological Hydrops fetalis

Chiba, Y.; Kobayashi, H.; Kanzaki, T.; Murakami, M 175

Development of Artificial Placenta: Oxygen Metabolism of Isolated Goat Fetuses with

Umbilical Arteriovenous Extracorporeal Membrane Oxygenation

Unno, N.; Kuwabara, Y.; Shinozuka, N.; Akiba, K; Okai, T.; Kozuma, S.; Mizuno, M. 189 Fetal

Cardiovascular Cross-Sectional Morphology of Tetralogy of Fallot in Rats

Momma, K; Ando, M.; Takao, A.; Wu, F.-F 196

Surfactant Maturation and Preterm Premature Membrane Rupture: A Case Study

James, D.K.; Eddowes, H.; Rodgers, A.; Harkes, A.; Williams, M 205

Fetal Tissue Transplantation Research and Federal Policy; A Growing Wall of Separation

Fletcher, J.C 211

Announcement

Author Index 226

Subject Index 227 